from the area. Moreover, data from Soviet studies based on much larger samples ${ }^{4}$ or the total population seem to have been arbitrarily dismissed. One of the most perturbing aspects of the published summary is the elimination of the estimates of increased incidences of cancer and leukaemia found in the original technical report. As the incidence of leukaemia is increasing rapidly and has now reached west European levels this omission raises some serious questions as to why this action was taken.

Clearly, future studies should contain sufficient numbers; be conducted prospectively over at least 20 years with reports at regular intervals; follow accepted standards of epidemiological investigation; and publicise the results in full for evaluation by the scientific community throughout the world. Future work should be undertaken by an independent body.

Chair, Chernobyl Disaster Fund for Health Care and Ecological Research in Byelorussia (CHERB), Sevenoaks TN14 6HS

\section{Secretary, CHERB,}

Birmingham B17 9UD

1 International Advisory Committee. International Chernobyl project. An overview. Vienna: International Atomic Energy Authority, 1991.

2 Darby SC, Reeves GK. Lessons of Chernobyl. BMJ 1991;303: 1347-8. (30 November.)

3 Mikhailenko YT, Matsidonskaya GF, Peterburgskaya VF. Content of thyroid hormones and placental lactogen in the blood of pregnant women suffering from hypertrophy of the thyroid pregnant women suffering from hypertrophy of the
gland. Public Health in Byelorussia 1990; June: 48-51.

gland. Public Health in Byelorussia 1990; June: 48 -51.
4 Lazyuk GI, Nokolaev DL, Ilyina EG. Hereditary malformations in children born in the south of Gomel and Mogilyev regions. in children born in the south of Gomel and Mogil
Public Health in Byelorussia 1990; June: 56-8.

5 Brennan M. The effects of the Chernobyl disaster. Birmingham: Chernobyl Disaster Fund for Health Care and Ecological Research in Byelorussia, 1991.

\section{Urinary incontinence}

SIR, - James O'Brien and colleagues found in a survey that $30 \%$ of patients with regular urinary incontinence who have discussed this problem with their general practitioner report having never received any form of assessment.' The authors express concern that, if their findings are representative of the situation in other health districts, a large burden of treatable unmet need exists.

Because of concern that some community services were being underused we undertook an anonymous postal survey of general practitioners in our district in June 1989. We received replies from 101 practitioners, of whom 42 reported never having used the continence advisory service for any of their elderly (aged >65) patients. Given the prevalence of urinary incontinence in the population aged 65 and over reported by O'Brien and colleagues $(16.0 \%$ in women and $13.3 \%$ in men), it seems unlikely that a lack of any suitable patients would account for this. Our findings suggest, furthermore, that difficulty in obtaining the service is unlikely to be a major explanation for never referring patients: two general practitioners reported usually or always having difficulty in referring to the service, 21 reported occasionally having difficulty, and 36 never had difficulty.

This non-referral to the continence advisory service is surprising, given that the service, led by a trained nurse continence adviser, has been well established and widely advertised for several years and is directly accessible to general practitioner referrals. O'Brien and colleagues quote previous concern that there is a widely held belief among the medical and nursing professions that incontinence is more of a nuisance than a real problem, ${ }^{2}$ and this may partly explain our results.

Our findings, based on a survey of general practitioners, and $O$ 'Brien and colleagues' findings, based on a survey of patients, lead to the same conclusion that a large burden of need is not being met, even when services are available. The reasons for this are not clear, and the issue merits further attention.

MARTIN BRIGGS

E S WILLIAMS

Department of Public Health Medicine,

Croydon Health Authority,

Croydon,

Surrey CR9 2RH

1 O'Brien J, Austin M, Sethi P, O'Boyle P. Urinary incontinence: prevalence, need for treatment, and effectiveness of intervenprevalence, need for treatment, and effectiveness of interve
tion by nurse. BMJ 1991;303:1308-12. (23 November.)

2 King's Fund. Action on incontinence. London: King's Fund, 1983. (Project paper No 43.)

\section{Urinary incontinence in women}

SIR, - Linda Cardozo suggests that urinary diversion should be considered earlier rather than later for young disabled women with urinary incontinence. ${ }^{1}$ Severe disability is not, however, necessarily a bar to learning how to perform self catheterisation as patients often show great ingenuity in their determination to gain control of their bladders. ${ }^{23}$

We studied 112 women aged 16-85 who attempted to use intermittent catheterisation. Eighty eight women had a neuropathic bladder, mainly due to spinal dysraphism, multiple sclerosis, intervertebral disc lesions, spinal tumour, or spina injury. Twenty four women had a non-neuropathic bladder, of whom a third had an atonic bladder associated with gynaecological problems. Although some women had no disability apart from incontinence, others were severely disabled and relied on wheelchairs. Many of these women, however, mastered the technique despite paraplegia, an anaesthetic perineum, intention tremor, severe spinal deformity, learning disability, old age, and even blindness. Their remarkable determination arose from the handicap imposed by incontinence, severe urinary infections, or episodes of acute retention. ${ }^{4}$

Cardozo recommends clean intermittent self catheterisation for patients with chronic urinary retention and overflow incontinence as it may enable them to become dry and safeguards the kidneys from the effects of back pressure and infection. ${ }^{5}$ As the technique is simple and safe and can be abandoned if unsuccessful with no long term side effects, ${ }^{6}$ it is always worth trying as an alternative to, or while a woman is awaiting, an operation. ${ }^{6}$ Some women have been so pleased with its results that they have continued with it in preference to surgery.

PIPPA OAKESHOTT GILLIAN M HUNT

Department of Urology,

Addenbrooke's Hospital

Cambridge CB2 2QQ

1 Cardozo L. Urinary incontinence in women: have we anything new to offer? BMY 1991;303:1453-7. (7 December.)

Hunt GM. Recent advances in intermittent catheterisation. $Z$ Kinderchir 1989;44(S):50.

3 Hunt GM, Whitaker RH. A new device for self catheterisation in wheelchair bound women. Br f Urol 1990;66:162-3
whe

4 Hunt GM, Whitaker RH, Doyle PT. Intermittent self catheterisation in adults. $B M \mathcal{F}$ 1984;289:467-8.

5 Underused: intermittent self catheterisation. Drug Ther Bull 1991;29:37-8.

6 Clean intermittent catheterisation. Lancet 1979;ii:981-3.

\section{Understanding Marfan's syndrome}

SIR, - Ian Young's editorial on Marfan's syndrome raises the problem of distinguishing patients with the syndrome from patients with similar conditions within a range of connective tissue disorders. ${ }^{1}$ The consequences of providing a diagnostic label may not be trivial for the patient. ${ }^{23}$
The Berlin nosology attempted to establish strict criteria for diagnosing Marfan's syndrome. ${ }^{+}$As Young comments, skeletal characteristics may be striking. We have studied families with no such skeletal features but with aortic dilatation and ectopia lentis and no relation fulfilling the criteria of the Berlin nosology. Another large family exhibits obvious skeletal features and several members of the family have aortic dissection but none show any eye signs. Ths large family did, however, show linkage to the fibrillin gene on chromosome 15 in the consortium study. In contrast to the above cases, one patient fulfils the criteria for Marfan's syndrome but does not have any evidence of aortic disease. How are we best to classify and, more importantly, counsel such patients? Will the first two families, which fail to qualify for the diagnosis of Marfan's syndrome, have a less serious prognosis than those that fulfil the criteria?

The perception of the term Marfan's syndrome, particularly among patients, is initially determined by family experiences. Families in which aortic dissection has resulted in death will regard it as a lethal condition, whereas those without such experience will not until advised that it is a risk of the condition. Raising such fears and the consequent need for regular monitoring is justified only if the risk is real. If patients labelled as having Marfan's syndrome do in fact have a heterogeneous collection of connective tissue disorders we can recognise disorders outside the strict criteria and should label them as "marfanoid" until we can determine with greater precision the risks concerned.

We hope that the progress in mapping the gene segregating with Marfan's syndrome and the finding of a decreased level of fibrillin in many patients with the syndrome ${ }^{6}$ will help to clarify these issues.

Departments of Pathology and Cardiology,

Ninewells Hospital,

Dundee DDI 9SY

1 Young I. Understanding Marfan's syndrome. BMf 1991;303 1414-5. (7 December.)

2 Glesby MJ, Pyeritz RE. Association of mitral valve prolapse and systemic abnormalities of connective tissue. JAMA and systemic

3 Bridges AB, Faed M, Boxer M, Gray JR, Bundy C, Murray A Marfan syndrome in a large family: response of family members to a screening programme. 7 Med Genet (in press).

4 Beighton P, de Paepe A, Danks D, Finidori G, Gedde-Dahl T, Goodman R, et al. International nosology of heritable disorders of connective tissue, Berlin, 1986. Am F Med Genet 1988;29: 581-94.

5 Tsipouras P, Sarfarazi M, Devi A, Weiffenbach B, Boxer B. Marfan syndrome is closely linked to a marker on chromosome 15q1.5->q2.1. Proc Natl Acad Sci USA 1991;88:4486-8.

6 Godfrey M, Menashe V, Welebers RG, Koler RD, Bigley RH, Lovrien E, et al. Cosegregation of elastin-associa:ed microfibrillar abnormalities with the Marfan phenotype in families. Am I Hum Genet 1990;46:652-60.

\section{Health of the nation: personality disorder}

SIR, - Mental illness in relation to The Health of the Nation was addressed by Graham Thornicroft and Geraldine Strathdee in the BMF's series of articles responding to the green paper, ${ }^{1}$ yet I believe that it is pertinent to highlight personality disorder, a subcategory of mental illness that often passes undiagnosed. Its prevalence is roughly $10 \%$ in the total population, rising to $20-30 \%$ in those attending general practices. ${ }^{2}$ When present with other diagnoses it worsens the prognosis, resulting in longer and more expensive treatment. Personality disorder is associated with target areas that have already been identified-namely, abnormal eating habits, alcohol and drug misuse, smoking, prevention of accidents, HIV and AIDS, and other mental illness itself. 